\title{
Surface Properties in Precise and Hard Machining
}

\section{Jan Madl}

Faculty of Production Technology and Management, University J.E. Purkyne in Ustí nad Labem, Na Okraji 1001, 40001/7 Ustí nad Labem, Czech Republic. E-mail: madl@fvtm.ujep.cz

Precision machining and especially hard machining is a topic of high interest at present. Surface integrity requirements increase. Hard precision machining may substitute some abrasive operations. There are some advantages of hard cutting over the abrasive machining. Abrasive machining has traditionally performed the finishing process of hardened steel. But, the availability of hard and super hard cutting tools enable the machine tools to reach surface quality of hard machining like to those obtained in grinding processes. A surface is not only a geometric entity but also a layer with its own structure and properties. These properties are affected by many factors, e. g. by cutting temperatures, friction, deformations in the primary deformation zone and the surface layer of the transient (machined) surface, by cutting tool geometry, work hardening, cutting environment, etc.

Keywords: surface integrity, precise machining, hard machining, residual stresses

\section{References}

[1] KONIG, W.; HOCHSCHULE, T.; KOMANDURI, R.; SCHENECTADY, D.; TONSHOFF, H.K. Machining of hard materials. Annals of the CIRP, 33 (2), 1984. pp. 417-427.

[2] NAKAYAMA, K.; ARAI, M.; KANDA, T. Machining characteristics of hard materials, Annals of the CIRP, 37(1), 1988. pp.89-92.

[3] TONSHOFF, H. K.; ARENDT, C.; BEN ARMOR, R., Cutting of hardened steel. Annals of the CIRP, 49(2), 2000. pp.547-566.

[4] ABRAO, A. M.; ASPINWALL, D. K., AND WISE, M.L.H. Tool wear, cutting forces and temperature evaluation when turning hardened bearing steel using PCBN and ceramics tool material. In Matador International Conferences, 1995. pp. 209-216.

[5] KONIG, W.; BERKTOLD, A.; KOCH, K. F. Turning versus grinding: A comparison of surface integrity aspects and attainable accuracies. Annals of the CIRP, 42(1), 1993. pp.39-43.

[6] EL-WARDANY, T.I.; KISHAWY, H. A.; ELBESTAWI, M.A. Surface integrity of die material in high speed hard machining, part 2 : Microhardness variations and residual stresses. ASME J. Manuf. Sci. Eng., 122, 2000. pp 632-641.

[7] LIU, C. R.; BARASH, M. M. Variables governing patterns of mechanical residual stress in a machined surface. Trans. ASME, Ser. B, 104, 1982. pp. 257-264.

[8] ELBESTAWI, M. A.; CHEN, L.; BECZE, C. E.; EL-WARDANY, T.I. High speed milling of dies and molds in their hardened state. Annals of the CIRP, 46(1), 1997. pp. 57-62.

[9] BOEHNER, J. \& DUMITRESCU, M. \& ELBESTAWI, M. A. \& EL-WARDANY, T.I. \& LIENJING CHEN. Effect of Carbide Tool Grades and Cutting Edge Geometry on Tool Life During High Speed Machining of Hardened Tool Steel. In $2^{\text {nd }}$ Int. Conf. on High Spee, 1996.

[10] HOLEŠOVSKÝ, F., HRALA, M., NOVÁK, M. Ground Surface - Quality and its Loading Capacity. Manufacturing Technology. Vol. 3, 2003. pp. 26-32.

[11] SUTANTO. H., MADL, J., Precision Milling of Hardened Steel with Ceramics and Cubic Boron Nitride Cutting Tools, Manufacturing Technology, Vol. 7/3, 2005.

[12] SUTANTO. H., MADL, J., Precision Milling of Hardened Steel Using Ceramics and Cubic Boron Nitride Cutting Tools, Manufacturing Technology, Vol. 10/2, 2005.

[13] HOLESOVSKY, F., HRALA, M. Analyze of Influence of New Abrasive Materials on Ground Surface. In.: Proceedings of 7th International Conference on Flexible Technologies, Novi Sad, Yugoslavia, 2000. pp.211212.

[14] MÁDL, J., RÁZEK V., KOUTNÝ, V., KAFKA, J. Surface Integrity in Notches Machining. Uetikon-Zurich: Trans Tech Publications, 2011. p. 176-181. ISBN 978-3-03785-297-2.

[15] KISHAWY, H.A., ELBESTAWI, M.A. Effects of Edge Preparation and Cutting Speed on Surface Integrity of Die Materials in Hard Machining. Proceeding of the ASME-IMECE, MED volume 8, 1998. pp. 269-276. 
[16] THIELE, J. D., MELKOTE, S. N., PEASCOE, R.A. and WATKINS, T.R. Effect of Cutting Edge Geometry and Workpiece Hardness on Surface Residual Stresses in Finish Hard Turning of AISI 52100 Steel. Transaction of $A S M E$, volume 122, 2000. pp. 642-649.

[17] KONIG, W., BERKTOLD, A. and KOCH, K. F. Turning versus Grinding : A Comparison of Surface Integrity Aspects and Attainable Accuracies. Annals of the CIRP, volume 42, no. 1, 1993. pp. 39-43.

[18] MADL, J., JERSAK, J., HOLESOVSKY,F., KOUTNY, V. and RAZEK, V.: Jakost Obrabenych Povrchu (Quality of Machined Surface), UJEP, UTRV, 2003. p 179, ISBN 80-7044-539-4.

[19] CHEN, WUYI Cutting Forces and Surface Finish when Machining Medium Hardness Steel using CBN Tools. International Journal of Machine Tools \& Manufacture, volume 40, 2000. pp. 455-466.

[20] DAVIES, M. A., CHOU, Y. and EVANS, C.J.: Tool Wear and Cutting Mechanics in Finish Hard Turning. Annals of the CIRP, volume 45, no. 1, 1996. pp. 77-82.

[21] KISHAWY, H. A., ELBESTAWI, M.A.: Effects of Process Parameters on Chip Morphology when Machining Hardened Steels. Manufacturing Science and Technology, ASME Bound Volume, MED volume 6, no. 2, 1997. pp. 13-20.

[22] SHAW, M. C, VYAS A. Chip Formation in the Machining of Hardened Steel. Annals of the CIRP, volume 42, no. 1, 1993. pp. 29-33.

[23] KISHAWI, H. A. ELBESTAWI M. A. Effects of Edge Preparation and Cutting Speed on Surface Integrity of Die Materials in Hard Machining. International Journal of Machine Tools \& Manufacture volume 9. 1999. pp. 1017-1030.

[24] CHOU, Y. K., EVANS C.J. AND BARASH W.W. Experimental Investigation on Cubic Boron Nitride Turning f Hardened AISI 52100 Steel. Journal of Materials Processing Technology, 2003, volume 134, pp. 1-9.

[25] SUTANTO, H., Precision Milling of Hardened Steel with Ceramics and Cubic Boron Nitride Cutting Tools. PhD. Thesis. CTU in Prague, Prague, 2004.

[26] PAPAZAFIRIOU, T. A., ELBESTAWI, M. A. Flank Wear Modeling in Milling. Journal of Mechanical Working Technology, volume 20, 1989. pp. 93-104.

[27] TAKATSU, S., SHIMODA, H. and OTANI, K. Effect of CBN Content on the Cutting Performance of Polycrystalline Cutting Tools. International Journal of Refractory and Hard Metals, volume 2, no. 4, 1983. pp. 175-178.

[28] MEHROTRA, P. K. Applications of Ceramic Cutting Tools. Advanced Ceramics Tools for Machining Applications III, 1998. pp. 1-23.

Paper number: M201234 